\title{
Self-perception of ethical behaviour: The case of listed Spanish companies
}

\author{
Maria José García López ${ }^{1}$, Oriol Amat ${ }^{2}$, Alfredo Rocafort ${ }^{3}$ \\ ${ }^{1}$ Universidad Rey Juan Carlos I, ${ }^{2}$ Universitat Pompeu Fabra, ${ }^{3}$ Universitat de Barcelona (Spain) \\ mariajose.garcia@urjc.es,oriol.amat@upf.edu,arocafort@ub.edu
}

\section{Abstract}

Purpose: This article aims to research into the perception that companies have of their ethical behavior.

Design/methodology/approach: A questionnaire was conducted in June 2014 among the listed companies that comprise the IBEX 35 index of Spanish stock exchanges. For the statistical analysis, contingency tables (double entry) were drawn up as well and several statistical tests (Cramer's V, Pearson's $x^{2}$, Kendall's correlation coefficient; and Goodman and Kruskal's Gamma).

Findings: The results show the self-perception that listed Spanish companies have of their ethical behaviour, with the observation that, generally, they have a greater perception than the reality of the study actually shows.

Research limitations/implications: Main limitations are that the sample size is small, although it includes the largest listed companies in the country. Respondents were essentially the Corporate Social Responsibility managers, so they may not be familiar with some of the subjects on which they were questioned, as we are dealing with large companies where responsibilities may be very compartmentalised.

Practical implications: This line of research helps to know more about the self perception of big Spanish listed companies about their ethical behavior. 
Social implications: The evidence provided by this study helps to know more about aspects than can be improved in connection the ethical behavior in companies. Recent scandals make the topic very relevant from a social point of view.

Originality/value: In recent years there has been much talk about the ethics of organisations and studies on the subject are plentiful. However, there has been scarcely any research into the perception that companies themselves have of their ethical behaviour.

Keywords: Ethical code, Listed companies, Spanish companies, Ethics, Sustainability

Jel Codes: M1

\section{Introduction}

In recent decades, the public's rising awareness in general and a concern about the responsibilities that companies have or could have towards society, have led to a growing interest in the development of business ethics. Ethics means following the principles and rules which determine a way of acting from a moral point of view. Ethics apply to all aspects of business conduct and are relevant to the conduct of both individuals and business organizations as a whole. Business ethics is a set of moral principles for reaching a decision within the values of the organisation (Holme, 2008). For Sylph (2009) ethics, like social norms, do not exist in a vacuum but must be evaluated in relation to actions, feelings and accepted thresholds. Business ethics refers to a movement within the activity or the movement to explicitly construct ethics in the structures of companies in the shape of ethics codes, ethics officers, ethics committees and ethical training (De George, 2010).

The transparency of companies has been a subject of little interest in the past, which meant that society was rarely able to know what was really happening in the business world. In the past, a company could survive simply by selling a sufficient amount and earning a sufficiently high profit to satisfy the needs of the owners, employees and suppliers. However, this point of view seems to have been dispelled: society has become sensitive to the ethical affairs of companies. The consequence of this has been the need for change in the business environment, as much in its internal structure as in its relationships with the outside world.

In agreement with Brooks (1989), the factors underlying the growing interest in business ethics policies are the generalised mistrust of business activity; the expectation of improving the well being of the local community; the need for certainty that executives do not act solely for their own profit but that they take into account the requests of all the stakeholders; the 
scandals that have occurred in the past and a greater interest from the public in general, based on rising awareness of the social and environmental impact that the actions of companies may have on certain resources and/or collectives. This interest in the behaviour of companies has been enhanced by increased media attention to the actions of corporations, as has been highlighted by Deegan and Rankin (1996), Gray, Kouhy and Lavers (1995), Hooghiemstra (2000) or Kolk (2003), among others.

This involves an important change of perspective which does not necessarily mean paying less attention to the main goal of the business, understood to be maximising profit, but rather to the notion that is a better way of doing things.

Ethics is a part of all human action and, hence, of business activity. Thus it is becoming ever more important that organisations stay true to their mission, their vision and their set values in order to face the dilemmas or issues that may arise during the course of their activity, since the breach of their own principles is becoming increasingly penalised by the market (Melé, 1994). The establishment of an ethical code must constitute the axis about which to structure the actions of the business, guiding its practices and negotiations in order to develop a suitable ethical behaviour. In this sense, it is also fundamental to implement proper governance policies with the goal of promoting ethics among employers and employees, since just as Argandoña (2008) indicates, how the boss behaves affects the ethical behaviour of the workers.

Ethics is a key ingredient to any well managed society (Noreen, 1988) and history has shown that when ethics is lost, social and economic confusion ensues. For this reason, as business scandals come to light, there is an increased pressure from society for ethics and, hence, normality, to be recovered, leaving the actions of companies under scrutiny. Several scandals in recent years, such as Enron and Parmalat in 2000, or Lehman Brothers and so many others which were the cause of the recent worldwide financial crisis, have made evident how a lack of ethical practices has led to a mass loss of trust in the integrity of the business community and a very sharp decline in the capital market (Blodget, 2008).

\section{The ethics of organisations}

Just as we previously showed, in recent decades and more intensely in recent years, the ethical behaviour of organisations has been put under the scrutiny of all their stakeholders. According to Nash (1992), the introduction of ethical practices and the development of ethical codes in companies tends to be triggered by events such as a scandal, the appointment of a new executive director, the retirement of one of the founders or the introduction of new legislation. There may be other reasons, but the significant point is that the institutionalisation 
of ethics in business and, more specifically, in the development and implementation of codes of good governance, has become an important social phenomenon in many organisations. Just as in their conception, present day business ethics entail a series of rules that must govern the behaviour of organisations and the establishment of procedures and measures that may allow compliance with these rules and turn them into companies with good values.

International markets have pressured companies to voluntarily reveal more information, not only about those intangible items that can be considered off-balance sheet, but also about their behaviour in relation to social and environmental actions, since ethics is not alien to this phenomenon (McLeay, 2004). The convergence between transparency and information has reduced the asymmetry between the actions of a company and what is known to its investors. From this point of view, asymmetry of information means agency costs and a lower valuation of the company, (Prencipe, 2004) corporations being aware of this and tending to ever more readily offer greater amounts of information to all the stakeholders that request it. Therefore, for any company, a greater transparency will give rise to a higher valuation, lower investment costs and a greater willingness to invest in the company (Gibbins, Richardson \& Waterhouse, 1990; Lev, 1992; Skinner, 1994; Watson, Shrives \& Marston, 2002).

However, on occasions there may be a difference between the perception that a corporation itself has of its actions and the information which it passes on to its stakeholders, with regard to what they expect. For companies, certain information which their stakeholders expect can involve an increase in costs and a source of competitive disadvantages (Ijiri, 1983; Cooke, 1989; Healy, Hutton \& Palepu, 1999; Prencipe, 2004; Cormier, Magnan \& Van Velthoven, 2005; Verrecchia, 1983) which they are not always willing to take on.

In the absence of a suitable regulatory framework, good corporate governance and high ethical standards are essential for long term business success (Robbins, Judge \& Campbell, 2010). There is extensive literature on the subject, mainly on ethical values and codes (Brooks, 1989; Cressey \& Moore, 1983; Dean, 1992; Molander, 1987; Osborne, 1991; Ryan, 1991; Weaver, 1993), on the organisational chain of ethics within organisations (Carter, 2000; Moberg, 2003; Kidd, 2003; Svensson, 2009), on environmental management (Best, 2004; Dummet, 2008; Natase \& Gligor-Cimpoieru, 2013) or about green marketing (Nantel \& Weeks, 1997; Crane, 2000; Chitakornkijsil, 2012). Other researchers have made comparative studies of ethical codes in different countries. For example, Schlegelmilch (1989) compares the United Kingdom and the USA, or Guillen, Guler and Muir (2002) analyse the differences between the large Spanish companies that have their headquarters in the USA and Spain, while Wood, Svensson, Singh, Carasco and Callaghan (2004) deal with the implementation of ethical codes in Australia, Canada and Sweden. 
On the other hand, many researchers have dedicated their efforts to study what the content of the ethical codes of organisations should be, this being defined as the written document containing the moral standards that must guide the behaviour of both employees and the business itself (Schwartz, 2002). Generally, it is considered that the ethical code must gather, as a minimum, basic principles of behaviour, general conduct guidelines, the relationship to the people in the company, the relationship with the market and the community; and the guidelines established for its monitoring and control.

While there have been some empirical studies about the ethical behaviour of listed companies (Golja \& Paulisic, 2010; Reverte, 2009; Broberg, Tagesson \& Collin, 2010), there has been scarcely any research about what perception companies have of their own ethical behaviour, this being the subject of study of our paper.

\section{Methodology}

The field study was conducted in June 2014 among the listed companies that comprise the IBEX 35 index of Spanish stock exchanges. The IBEX 35 index is the main benchmark stock index of the Spanish stock exchange and comprises the 35 companies with the most liquidity which are listed on the four Spanish stock exchanges (Madrid, Barcelona, Bilbao and Valencia). Over the course of 2014 there were two exits from the index by companies, so that the total number of companies to have been part of IBEX 35 was 37. These companies are highly representative, as their capitalization and trading account for over $75 \%$ of the total in Spanish stock exchanges. In addition, the added value generated by companies that comprise the IBEX is about $30 \%$ of that of listed and unlisted Spanish companies. Therefore, although it consists of a small number of companies, it carries great weight within the whole of the country's companies. An appointment was arranged via email and the Corporate Social Responsibility Managers or, in their absence, the Directors General were given a telephone interview. In total,30 companies replied, making the response rate $81.08 \%$ of the total of 37 companies contacted.

The questionnaire was devised to explore the perception that the respondent had with respect to:

- the content of the ethical code regarding the company's policies;

- participation in international initiatives relating to ethics and sustainability;

- the adoption of environmental programmes, 
- the training of employees in the ethical code and the involvement of the Board of Directors in this process and

- the adopted initiatives in favour of the workers.

For the statistical analysis, contingency tables (double entry) were drawn up as well as the following statistical tests which relate the proposed variables.

In order to address the data collected as simply qualitative variables, a Cramer's V statistical test was made, applicable to the Chi Squared coefficient and being significant for values above $v>0.5$, the formula of which is:

$$
V=\sqrt{\frac{X^{2}}{N \cdot m}}
$$

Pearson's $\mathrm{x}^{2}$ test is a parametric test which analyses the independence of two variables to each other, by presenting data in contingency tables, being significant for values below 0.05 and whose formulais:

$$
\mathrm{X}^{2}=\sum \frac{\text { (observed } \left._{\mathrm{i}}-\text { theoretical }_{\mathrm{i}}\right)^{2}}{\text { theoretical }_{\mathrm{i}}}
$$

Kendall's correlation coefficient, more well known as Kendall's tau, is used for studying statistical dependency based on the tau coefficient, being significant for $\mathrm{T} \geq 0.5$ (in absolute value) and the formula for which is:

$$
T=\frac{\text { (number of concordant pairs })-(\text { number of discordant pairs })}{\frac{1}{2} n(n-1)}
$$

And Goodman and Kruskal's Gamma test, which is used with contingency tables, being significant for values for which $\urcorner>0.5$ and which is defined as:

$$
\urcorner=\frac{P_{c}-P_{d}}{------}
$$

The results of the study are presented below. 


\section{Results}

Generally, all respondents expressed their conviction that the ethical standards of their company are maximal. However, as described in the following sections, several incoherences have been identified between the general perception of the ethical behaviour of companies and its reflection in ethical codes and other related policies.

\subsection{Content of the ethical code with respect to the company's policies}

In this first section, the correlation between company policies and the updating of the ethical code has been analysed. For this, the policies that it is thought should be part of a review of the ethical code have been considered (see Table 1).

\begin{tabular}{|l|r|r|r|r|}
\cline { 2 - 4 } \multicolumn{1}{c|}{} & Cramer's V & Pearson & \multicolumn{1}{c|}{ Gamma } & Kendall's tau \\
\hline Anti-trust/competition policies & 0.4787 & 0.186 & 0.0370 & 0.0233 \\
\hline Fair treatment & 0.3844 & 0.376 & 0.0127 & 0.0077 \\
\hline Gifts & 0.6287 & 0.040 & 0.1746 & 0.0991 \\
\hline Lobbying & 0.5627 & 0.084 & 0.1765 & 0.1019 \\
\hline Bribery and corruption & 0.5627 & 0.084 & 0.1765 & 0.1019 \\
\hline Data protection & 0.5362 & 0.110 & 0.3429 & 0.2039 \\
\hline $\begin{array}{l}\text { Security and confidentiality of } \\
\text { information }\end{array}$ & 0.8165 & 0.003 & 0.5000 & 0.2443 \\
\hline Social networks & 0.6216 & 0.044 & 0.0233 & 0.2632 \\
\hline Use of inside information & 0.4601 & 0.217 & 0.3425 & 0.0154 \\
\hline $\begin{array}{l}\text { Documentation management } \\
\text { and retention }\end{array}$ & 0.4260 & 0.283 & 0.3421 & 0.2035 \\
\hline Financial integrity and fraud & 0.5362 & 0.110 & 0.3429 & 0.2054 \\
\hline Money laundering & 0.2387 & 0.754 & 0.2917 & 0.2039 \\
\hline Supply chain management & 0.4601 & 0.217 & 0.3425 & 0.1368 \\
\hline $\begin{array}{l}\text { Employment and labour } \\
\text { standards }\end{array}$ & 0.1894 & 0.868 & 0.2364 & 0.2035 \\
\hline Equal opportunities & 0.3344 & 0.503 & 0.0345 & 0.1171 \\
\hline Harassment in the workplace & 0.5903 & 0.062 & 0.5938 & 0.0131 \\
\hline Environmental protection & 0.3162 & 0.552 & 10.000 & 0.3424 \\
\hline Health and safety at work & 0.4610 & 0.216 & 0.7647 & 0.2523 \\
\hline Tayy & & 0.2342
\end{tabular}

Table 1 . Correlation between company policies and the updating of the ethical code

The analysis shows that there is a direct correlation between the updating of the ethical code and the policies defined by the company in areas such as conflict of interests; gifts, lobbying, bribery and corruption; data protection; security and confidentiality of information; social networks; financial integrity and fraud; and harassment in the workplace. On the other hand, it has brought to light a direct correlation between the updating of the ethical code and the rest 
of independent policies which the code must contain (anti-trust/competition policies; fair treatment; use of inside information; documentation management and retention; money laundering; supply chain management; employment and labour standards; equal opportunities; environmental protection; and health and safety at work).

\subsection{Participation in international initiatives relating to ethics and sustainability}

Regarding the participation in international initiatives relating to ethics and sustainability, the chief variables were both the frequency of updates of the ethical code and the date of the last update. The results are shown in Tables 2 and 3.

\begin{tabular}{|l|r|r|r|r|}
\cline { 2 - 4 } \multicolumn{1}{c|}{} & Cramer's V & Pearson & \multicolumn{1}{c|}{ Gamma } & \multicolumn{1}{c|}{ Kendall's tau } \\
\hline United Nations Global Compact & 0.3227 & 0.534 & 0.7297 & 0.2961 \\
\hline Anti-Corruption Forum & 0.3536 & 0.453 & 0.3846 & 0.1645 \\
\hline Forum Against Climate Change & 0.8122 & 0.003 & 0.5298 & 0.4277 \\
\hline Corporate Global Citizenship Forum & 0.5204 & 0.128 & 0.6279 & 0.2961 \\
\hline $\begin{array}{l}\text { World Business Council for } \\
\text { Sustainable Development }\end{array}$ & 0.5204 & 0.128 & 0.6279 & 0.2961 \\
\hline International Transparency & 0.4136 & 0.309 & 0.0769 & 0.0261 \\
\hline Global Reporting Initiative & 0.3092 & 0.571 & 0.5652 & 0.2541 \\
\hline Carbon Disclosure Project & 0.3162 & 0.552 & 10000 & 0.2523 \\
\hline
\end{tabular}

Table 2. Correlation between participation in international initiatives in favour of sustainability and the frequency of updates of their ethical code

\begin{tabular}{|c|c|c|c|c|}
\hline & Cramer's V & Pearson & Gamma & Kendall's tau \\
\hline United Nations Global Compact & 0.4682 & 0.095 & 10000 & 0.3677 \\
\hline Anti-Corruption Forum & 0.3022 & 0.449 & 0.4430 & 0.1994 \\
\hline Forum Against Climate Change & 0.1826 & 0.809 & 0.1826 & 0.0964 \\
\hline Corporate Global Citizenship Forum & 0.4940 & 0.069 & 0.9104 & 0.3936 \\
\hline $\begin{array}{l}\text { World Business Council for Sustainable } \\
\text { Development }\end{array}$ & 0.4940 & 0.069 & 0.9104 & 0.3936 \\
\hline International Transparency & 0.2015 & 0.759 & 0.3611 & 0.1481 \\
\hline Global Reporting Initiative & 0.5193 & 0.050 & 0.4444 & 0.2718 \\
\hline Carbon Disclosure Project & 0.2605 & 0.579 & 10000 & 0.2046 \\
\hline
\end{tabular}

Table 3. Correlation between participation in international initiatives in favour of sustainability and the last review of their ethical code

In this case the participation of the business in international initiatives in favour of sustainability is significant, regardless of when the last review of its ethical code was or what its update frequency is. The companies analysed participate mostly in initiatives such as the Forum Against Climate Change, the Corporate Global Citizenship Forum, and the World 
Business Council for Sustainable Development. However, they acknowledge a lower participation in other international initiatives such as the United Nations Global Compact, the Anti-Corruption Forum, Transparency International, and the Carbon Disclosure Project.

\subsection{Adoption of environmental programmes}

The third part of the survey attempted to establish the relationship between the adoption of measures for environmental protection and the ethical code of the listed companies, with the results shown in Tables 4 and 5.

\begin{tabular}{|c|c|c|c|c|}
\hline & Cramer's V & Pearson & Gamma & Kendall's tau \\
\hline $\begin{array}{l}\text { Environmental performance } \\
\text { measurement }\end{array}$ & 0.4476 & 0.240 & 0.8367 & 0.4007 \\
\hline Carbon footprint accounting & 0.3953 & 0.350 & 0.7143 & 0.3604 \\
\hline Energy certificate & 0.3227 & 0.534 & 0.7297 & 0.2961 \\
\hline Use of renewable energy & 0.3953 & 0.350 & 0.7143 & 0.3604 \\
\hline Waste management & 0.3162 & 0.552 & 10000 & 0.2523 \\
\hline Water management & 0.3513 & 0.459 & 0.4828 & 0.2523 \\
\hline Biodiversity & 0.6077 & 0.051 & 0.3412 & 0.2228 \\
\hline
\end{tabular}

Table 4. Correlation between the company's adoption of environmental programmes and the frequency of updates of their ethical code

\begin{tabular}{|c|c|c|c|c|}
\hline & Cramer's V & Pearson & Gamma & Kendall's tau \\
\hline $\begin{array}{l}\text { Environmental performance } \\
\text { measurement }\end{array}$ & 0.4476 & 0.240 & 0.8367 & 0.4007 \\
\hline Carbon footprint accounting & 0.3953 & 0.350 & 0.7143 & 0.3604 \\
\hline Energy certificate & 0.3227 & 0.534 & 0.7297 & 0.2961 \\
\hline Use of renewable energy & 0.3953 & 0.350 & 0.7143 & 0.3604 \\
\hline Waste management & 0.3162 & 0.552 & 10000 & 0.2523 \\
\hline Water management & 0.3513 & 0.459 & 0.4828 & 0.2523 \\
\hline Biodiversity & 0.6077 & 0.051 & 0.3412 & 0.2228 \\
\hline
\end{tabular}

Table 5. Correlation between the company's adoption of environmental programmes and the last review of their ethical code

Just as may be observed, in this case there is no correlation between the update or last revision of the ethical code and the adoption of environmental programmes, except in the case of biodiversity. We consider that in this case, and given the profile of the respondents who were, as aforementioned, the Corporate Social Responsibility (CSR) managers of the companies surveyed, they may consider that the adoption of these policies or programmes comes under their sustainability strategy rather than their ethical code. 


\subsection{Training of employees in the ethical code and the involvement of the Board of Directors and company directors}

In the next section we considered the training of employees in the ethical code and the involvement of the Administrative Board, considering that some of the basic features that ethical codes must gather is both the training of all the staff as well as the supervision and control by an authority which the company considers to be competent. The results of the study are shown in Tables 6 and 7.

\begin{tabular}{|l|r|r|r|r|}
\cline { 2 - 4 } & \multicolumn{3}{|l|}{$\begin{array}{l}\text { The Board of Directors is actively committed } \\
\text { to supervising the compliance and ethics of } \\
\text { the organisation programme. }\end{array}$} \\
\cline { 2 - 5 } & Cramer's V & \multicolumn{1}{|c|}{ Pearson } & \multicolumn{1}{|c|}{ Gamma } & Kendall's tau \\
\hline $\begin{array}{l}\text { It is part of the induction process for } \\
\text { new employees. }\end{array}$ & 0.6506 & 0.002 & 0.7500 & 0.4533 \\
\hline $\begin{array}{l}\text { Takes place periodically, at least every } 1 \\
\text { or 2 years }\end{array}$ & 0.3093 & 0.238 & 0.3077 & 0.0629 \\
\hline $\begin{array}{l}\text { Content is revised and updated } \\
\text { periodically }\end{array}$ & 0.4000 & 0.091 & 0.6000 & 0.2200 \\
\hline Includes acknowledgement procedures & 0.3430 & 0.171 & 0.4643 & 0.0792 \\
\hline There is monitoring until completion & 0.4564 & 0.040 & 0.1053 & 0.0887 \\
\hline Includes tests & 0.3025 & 0.253 & 0.3621 & 0.2720 \\
\hline The results of the tests are monitored & 0.1547 & 0.698 & 0.0377 & 0.1572 \\
\hline $\begin{array}{l}\text { It is part of a worker's performance } \\
\text { evaluation }\end{array}$ & 0.2187 & 0.488 & 0.1154 & 0.2516 \\
\hline
\end{tabular}

Table 6. Commitment from the Board of Directors to supervise the training in ethical code programme

In relation to the Administrative Board's commitment to supervise the training in the ethical code programme, there is only one significant piece of evidence regarding the incorporation of training in the ethical code with the induction process of new employees while there appears to be no specific relationship with the rest of the aspects considered, such as updating the training, its monitoring or the participation in the worker's performance evaluation. 


\begin{tabular}{|c|c|c|c|c|}
\hline & \multicolumn{4}{|c|}{$\begin{array}{l}\text { Senior managers in our company regularly } \\
\text { and consistently talk to employees about } \\
\text { appropriate norms of conduct, ethics and } \\
\text { compliance. }\end{array}$} \\
\hline & Cramer's V & Pearson & Gamma & Kendall's tau \\
\hline $\begin{array}{l}\text { It is part of the induction process for } \\
\text { new employees. }\end{array}$ & 0.8262 & 0.000 & 0.6535 & 0.4205 \\
\hline $\begin{array}{l}\text { Takes place periodically, at least every } 1 \\
\text { or } 2 \text { years }\end{array}$ & 0.6030 & 0.017 & 0.0986 & 0.0629 \\
\hline $\begin{array}{l}\text { Content is revised and updated } \\
\text { periodically }\end{array}$ & 0.5422 & 0.041 & 0.3521 & 0.2200 \\
\hline Includes acknowledgement procedures & 0.5422 & 0.041 & 0.1268 & 0.0792 \\
\hline There is monitoring until completion & 0.1873 & 0.806 & 0.1515 & 0.0887 \\
\hline Includes tests & 0.3608 & 0.303 & 0.4493 & 0.2720 \\
\hline The results of the tests are monitored & 0.2677 & 0.571 & 0.2756 & 0.1572 \\
\hline $\begin{array}{l}\text { It is part of a worker's performance } \\
\text { evaluation }\end{array}$ & 0.3882 & 0.239 & 0.4242 & 0.2516 \\
\hline
\end{tabular}

Table 7. Commitment from the directors/executives to supervise the training in ethical code programme

However, we did find a significant relationship when analysing the executives/directors, as being responsible for their teams, regarding the supervision of the training in the ethical code programme. This commitment has been identified in relation to new employees and to more senior employees who also update their knowledge of the content of the ethical code.

\subsection{Policies in favour of workers and the work environment}

Finally, the relationship between the frequency of updating the ethical code and the implementation of policies in favour of the workers were studied, with the results shown in Table 8.

\begin{tabular}{|c|c|c|c|c|}
\hline & Cramer's V & Pearson & Gamma & Kendall's tau \\
\hline Diversity & 0.4699 & 0.200 & 0.6176 & 0.3568 \\
\hline Leadership training & 0.2387 & 0.754 & 0.2917 & 0.1368 \\
\hline Mentoring & 0.5405 & 0.105 & 0.3151 & 0.3151 \\
\hline Education funding & 0.2789 & 0.652 & 0.0145 & 0.0081 \\
\hline Pensions & 0.3519 & 0.457 & 0.3165 & 0.1921 \\
\hline Medical insurance & 0.4476 & 0.240 & 0.8367 & 0.4007 \\
\hline Gym & 0.4601 & 0.217 & 0.3425 & 0.2035 \\
\hline Health and prevention programmes & 0.2387 & 0.754 & 0.2917 & 0.1368 \\
\hline Flexitime & 0.4699 & 0.200 & 0.6176 & 0.3568 \\
\hline Teleworking & 0.7862 & 0.005 & 10000 & 0.7222 \\
\hline Volunteering & 0.4610 & 0.216 & 0.7647 & 0.2342 \\
\hline
\end{tabular}

Table 8. Relationship between the frequency of updating the ethical code and the implementation of policies in favour of the workers 
Just as the results show, the only significant inclusions are mentoring programmes and teleworking, bringing to light other issues that should be gathered in the ethical code, such as for example, diversity.

\section{Conclusions}

The main goal of this work has been to investigate what perception listed companies have of their own ethical behaviour. For this purpose the companies that comprise the most relevant stock index of the Spanish stock exchange were surveyed. The study has highlighted the following conclusions:

- While the perception that listed Spanish companies have of their ethical behaviour is high, it was found that their conduct was not significantly guided by the inclusion of independent ethical policy.

- On the other hand, there is no significant correlation between the ethical code and the participation in international initiatives relating to ethics and sustainability, with the exception of the Forum Against Climate Change, the Corporate Global Citizenship Forum andthe World Business Council for Sustainable Development. The same thing occurred when trying to establish the relationship between environmental programmes and the ethical code, as there was no significant correlation between the variables under study.

- Given the importance of training in matters of the ethical code, a significant role of the Board of Directors was highlighted in the process of supervising training in the ethical code for new employees. The involvement of the directors/executives during the monitoring, update, review and control of this training was also brought to light, which we consider suitable as they actin a supervisory role over their workers.

- Finally, there was no correlation found between the inclusion of measures in the companies in favour of the workers and the ethical code, with the exception of matters referring to mentoring and telework. We consider that in this case, it is because, just like environmental programmes, they are considered actions, measures and programmes more closely related to corporate social responsibility and strategic planning than tothe ethical code of the company.

Given that the goal of this work is to analyse the self-perception of companies about their actions in affairs relating to ethics, there has been no comparison between the views expressed and the reality of the situation. Therefore, there may be differences between the directors' views and what the companies really do. On the other hand, this work has several limitations. Among them we can highlight that the sample size is small, although it includes the 
largest listed companies in the country. Hence, their situation may differ from that of smaller companies. It must also be noted that the respondents were essentially the Corporate Social Responsibility managers. Therefore they may not be familiar with some of the subjects on which they were questioned, as we are dealing with large companies where responsibilities may be very compartmentalised.

As for further study of this subject there are several possible future areas of investigation. One possibility for extending the work would be to increase the number of companies analysed to include smaller organisations. This would allow the impact of size to be evaluated in the subject under study. Secondly, the questionnaire could extend to other directors in the companies who are also involved in the subject under study, such as Human Resources Managers. Another issue of great interest could be to corroborate that the self-perception of the executives/directors surveyed corresponds to the reality of business practices. Ultimately, there are several possibilities open that could hugely enrich what is known about a subject of great scientific and business relevance.

\section{References}

ARGANDOÑA, A. (2008). The stakeholder theory and the common good. Journal of Business Ethics, 17(9-10): 1093-1102.

BEST, K. (2004). Interfacing the Environment: Networked screens and the ethics of visual consumption. Ethics and the Environment, 9.2(Fall 2004): 65-85. http://dx.doi.org/10.2979/ETE.2004.9.2.65

BLODGET, H. (2008). Why Wall Street Always Blow It. The Atlantic Quarterly, 302(5): 50-60

BROBERG, P.; TAGESSON, T.; COLLIN, S.O. (2010). What explain variation in voluntary disclosure? A study of the annual reports of corporations listed on the Stockholm Stock Exchange. Journal of Management and Governance, 14(4): 351-377. http://dx.doi.org/10.1007/s10997-009-9104-y

BROOKS, L. (1989). Corporate Codes of Ethics. Journal of Business Ethics, 8: 117-129. http://dx.doi.org/10.1007/BF00382576

CARTER, C.R. (2000). Ethical issues in international buyer-supplier relationships: A dyadic examination. Journal of Operations Management, 18(2): 191-209. http://dx.doi.org/10.1016/S0272-6963(99)00016-9 
CHITAKORNKIJSIL, P. (2012). Moral meaning in green marketing and socially responsible marketing. International Journal of Organizational Innovation, (Online) 4.3(Winter 2012): 113-128.

COOKE, T.E. (1989). Voluntary Corporate Disclosure by Swedish Companies. Journal of International Financial Management and Accounting, 1(2): 171-195. http://dx.doi.org/10.1111/j.1467-646X.1989.tb00009.x

CORMIER, D.; MAGNAN, M.; VAN VELTHOVEN, B. (2005). Environmental disclosure quality in large German companies: Economic incentives, public pressures or institutional conditions?. European Accounting Review, 14(1): 3-39. http://dx.doi.org/10.1080/0963818042000339617

CRANE, A. (2000). Marketing and the natural environment: What role for morality?. Journal of Macro Marketing, 20(2): 144-154. http://dx.doi.org/10.1177/0276146700202004

CRESSEY, D.R.; MOORE, C.A. (1983). Managerial Values and Corporate Codes of Ethics. California Management Review, 25(4): 53-77. http://dx.doi.org/10.2307/41165032

DE GEORGE, R.T. (2010). A History of Business Ethics. Available online at: http://www.scu.edu/ethics/practicing/focusareas/business/conference/presentations/business-ethics-history.html. (Last access date: April 25th, 2010).

DEAN, P.J. (1992). Making Codes of Ethics Real. Journal of Business Ethics, 11: 285-290. http://dx.doi.org/10.1007/BF00872170

DEEGAN, C.; RANKIN, M. (1996). Do Australian Companies Report Environmental News Objectively? An Analysis of Environmental Disclosures by Firms Prosecuted Successfully by the Environmental Protection Authority. Accounting, Auditing \& Accountability Journal, 9(2): 50-67. http://dx.doi.org/10.1108/09513579610116358

DUMMET, K. (2008). Corporate Environmental Responsiblity. Available online at: http://www.researchbank.rmit.edu.au

GIBBINS, M.; RICHARDSON, A.; WATERHOUSE, J. (1990). The management of corporate financial disclosures: Opportunism, ritualism, policies and processes. Journal of Accounting Research, 28(1): 121-143. http://dx.doi.org/10.2307/2491219

GRAY, R.; KOUHY, R.; LAVERS, S. (1995). Corporate Social and Environmental Reporting: A Review of the Literature and a Longitudinal Study of UK Disclosure. Accounting, Auditing \& Accountability Journal, 8(2): 47-77. http://dx.doi.org/10.1108/09513579510146996

GOLJA, T.; PAULISIC, M. (2010). Corporate governance, social responsibility and corporate reputation: An empirical analysis of the situation in Croatia. International Journal of Economic Policy in Emerging Economies, 368-384. 
GUILLEN, M.; GULER, I.; MUIR, J. (2002). Global Competition, Institutions, and the Diffusion of Organizational Practices: The International Spread of the ISO 9000 Quality Certificates. Administrative Science Quarterly, 47(June): 207-232.

HEALY, P.; HUTTON, A.P.; PALEPU, K.G. (1999). Stock performance and intermediation changes surrounding sustained increases in disclosure. Contemporary Accounting Research, 16(3): 485-520. http://dx.doi.org/10.1111/j.1911-3846.1999.tb00592.x

HOLME, C. (2008). Business ethics - Part One: Does it mat-ter?. Industrial and Commercial Training, 40(5): 248-252. http://dx.doi.org/10.1108/00197850810886487

HOOGHIEMSTRA, R. (2000). Corporate Communication and Impression Management: New Perspectives Why Companies Engage in Corporate Social Reporting. Journal of Business Ethics, 27(1/2): 55-68. http://dx.doi.org/10.1023/A:1006400707757

IJIRI, Y. (1983). On the accountability-based conceptual framework of accounting. Journal of Accounting and Public Policy, 2(2): 75-81. http://dx.doi.org/10.1016/0278-4254(83)90001-7

KIDD, J. (2003). Learning and trust in supply chain management: Disintermediation, ethics and cultural pressures in brief dynamic alliances. International Journal of Logistics: Research \& Applications, 6(4): 259-276. http://dx.doi.org/10.1080/13675560310001626972

KOLK, A. (2003). Trends in Sustainability Reporting by the Fortune Global 250. Business Strategy and the Environment, 12(5): 279-291. http://dx.doi.org/10.1002/bse.370

LEV, B. (1992). Information disclosure strategy. California Management Review, 34(summer): 9-32.

MCLEAY, S. (2004). International financial analysis. In C. Nobes\& R. Parker (Eds.), Comparative international accounting (8th ed., pp. 463-484). London: Pearson Education.

MELÉ, D. (1994). Códigos de conducta empresarial: ¿Pueden contribuir al desarrollo ético de los empleados?. Research paper DI-279 (IESE Business School, Barcelona, Spain).

MOBERG, C.R. (2003). Evaluating the relationship between questionable business practices and the strength of supply chain relationships. Journal of Business Logistics, 24(2): 1-19. http://dx.doi.org/10.1002/j.2158-1592.2003.tb00043.x

MOLANDER, E.A. (1987). A Paradigm for Design, Promulgation and Enforcement of Ethical Codes. Journal of Business Ethics, 6: 619-631. http://dx.doi.org/10.1007/BF00705778

NANTEL, J.; WEEKS, W. (1997). Marketing ethics: Is there more to it than utilitarian approach?. European Journal of Marketing, 30(5): 9-19. 
NASH, L.L. (1992). A survey of three stages in the evolution of corporate ethics programs. Ethikos, 5(6): 1-3, 11.

NATASE, M.; GLIGOR-CIMPOIERU, D.C. (2013). A Plea for the Importance of Business Ethics Education for Future Managers in an International Competitive Environment. Journal of International Management, 14.2(May): 191-201.

NOREEN, E. (1988). The Economics of Ethics: A New Perspective on Agency Theory. Accounting, Organizations and Society, 13(4): 359-369. http://dx.doi.org/10.1016/03613682(88)90010-4

OSBORNE, R. (1991). Core Value Statements: The Corporate Compass. Business Horizons, 34: 28-32. http://dx.doi.org/10.1016/0007-6813(91)90043-U

PRENCIPE, A. (2004). Proprietary Costs and Determinants of Voluntary Segment Disclosure: Evidence from Italian Listed Companies. European Accounting Review, 13(2): 319-340. http://dx.doi.org/10.1080/0963818042000204742

REVERTE, C. (2009). Determinants of corporate social responsibility disclosure ratings by Spanish listed firms. Journal of Business Ethics, 88(2): 351-366. http://dx.doi.org/10.1007/s10551-008-9968-9

ROBBINS, S.P.; JUDGE, T.A.; CAMPBELL, T.T. (2010). Organisational Behaviour. UK: Prentice Hall.

RYAN, L.V. (1991). Conflicts Inherent in Corporate Codes. Journal of Value Based Management, 4(1): 119-137. http://dx.doi.org/10.1007/BF01714897

SCHLEGELMILCH, B. (1989). The Ethics Gap between Britain and the United States: A Comparison of the State of Business Ethics in both Countries. European Management Journal, 7(1): 57-64. http://dx.doi.org/10.1016/0263-2373(89)90144-8

SKINNER, D. (1994). Why firms voluntarily disclose bad news. Journal of Accounting Research, 32(Spring): 38-60. http://dx.doi.org/10.2307/2491386

SVENSSON, G. (2009). The transparency of SCM-ethics: Conceptual framework and empirical illustrations. Supply Chain Management: An International Journal, 14(4): 259-269. http://dx.doi.org/10.1108/13598540910970090

SCHWARTZ, M. (2002). A code of ethics for corporation code of ethics. Journal of Business Ethics, 41: 27-43. http://dx.doi.org/10.1023/A:1021393904930

SYLPH, J.M. (2009). Corporate governance and ethics. Dubai International Financial Centre, Seminar, 12th March 2009. 
VERRECCHIA, R.E. (1983). Discretionary disclosure. Journal of Accounting and Economics, 5: 179-194. http://dx.doi.org/10.1016/0165-4101(83)90011-3

WATSON, A.; SHRIVES, P.; MARSTON, C. (2002). Voluntary disclosure of accounting ratios in the UK. British Accounting Review, 34: 289-313. http://dx.doi.org/10.1006/bare.2002.0213

WEAVER, G.R. (1993). Corporate Codes of Ethics: Purpose, Process and Content Issues. Business \& Society, 32(1): 44-58. http://dx.doi.org/10.1177/000765039303200106

WOOD, G.G.; SVENSSON, J.; SINGH, E.; CARASCO, G.; CALLAGHAN, M. (2004). Implementing the Ethos of Corporate Codes of Ethics: Australia, Canada, and Sweden. Business Ethics: $A$ European Review, 13(4): 15-26. http://dx.doi.org/10.1111/j.1467-8608.2004.00378.x

Intangible Capital, 2016 (www.intangiblecapital.org)

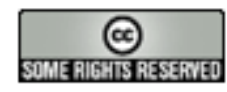

Article's contents are provided on an Attribution-Non Commercial 3.0 Creative commons license. Readers are allowed to copy, distribute and communicate article's contents, provided the author's and Intangible Capital's names are included. It must not be used for commercial purposes. To see the complete license contents, please visit http://creativecommons.org/licenses/by-nc/3.0/. 